\title{
К ДВАДЦАТИЛЕТИЮ ИНСТИТУЦИОНАЛЬНОГО РАЗДЕЛЕНИЯ ВЛАСТИ В РОССИИ: УРОКИ ФРАНЦУЗСКОЙ КОНСТИТУЦИИ 1958 ГОДА
}

\begin{abstract}
Аннотация: Данная работа посвящена сравнительному анализу основных государственных институтов России и Франциии, закрепленных действующими конституцуиями этих стран. Особое внимание уделено институцииональному разделению власти, для анализа которого используется предложенная авторами оригинальная версия институционального подхода и разработанная на его основе институционально-функциональная теория государства. В рамках данной теории становится возможным развитие классической теории разделения властей на основе нового понятия «институциональных компонентов власти». Это позволяет авторам рассмотреть особенности института Президента (президентуры) и конституциионного контроля/надзора, а также конституциионных механизмов взаимодействия институциональных компонентов власти в России и Франции. Для анализа франиузской модели институционального разделения власти используется комментарий к Конституции Франиузской Республики 1958 года, написанный одним из создателей этой модели Ги Каркассонном и опирающийся на кониепцию «современной демократии» как развитой формы правового государства в стране, достигшей высокого уровня политико-правового развития. На основе этой концепции дается ответ на вопрос о том, что превратило Франциию в современную демократию именно в период V Республики и какие уроки может извлечь из французского опыта Россия, заимствующяая, как показано в работе, многие черты конституционного устройства современной Франиии.
\end{abstract}

Abstract: This article is devoted to the comparative analysis of the key state institutions of Russia and France, as provided for by the current Constitutions of these states. Much attention is paid to the institutional separation of powers, and the authors use an original institutional method and the institutional functional theory of state for its analysis. Within the framework of this theory the classic theory of separation of powers can be developed on the basis of "institutional components of power". It allows the authors to evaluate the specific features of the institution of the President and constitutional control/supervision, as well as the constitutional mechanisms for the interaction of institutional components in Russia and in France.

For the analysis of the French model of institutional separation of powers the authors use the Commentary to the Constitution of the French Republic of 1958, which was written by one of the founders of this model Guy Carcassonne, and which is based upon the concept of "modern democracy" as the developed form of the rule-of-law state in a state with high political and legal development. Based upon this concept the authors give their response to the question of what made France a modern democracy at the time of the V Republic, and what the lessons we are to learn from the constitutional structure of modern France.

Ключевые слова: правовое государство, современная демократия, конституционализм, институциональное разделение власти, институцииональнье компоненты власти, президентская власть, конституционная власть, Франиия, Россия, президентура

Keywords: rule-of-law state, modern democracy, constitutionalism, institutional separation of powers, institutional components of power, presidential power, constitutional power.

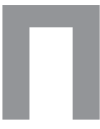

разднование двадцатилетия Конституции Российской Федерации 1993 года - прекрасный повод вспомнить о том, что Россия, как и другие государства бывшего Советского Союза, все это время двигалась - быть может, непоследовательно и не слишком быстро, но двигалась - по пути строительства демократического правового государства, стремящегося гарантировать и защищать права граждан и основанного на идее институцционального самоограничения власти. Этот процесс нашел свое воплощение в развитии российского конституцииоализма. Конституция Российской Федерации 1993 года впервые в российской истории на высшем законодательном уровне закрепила институциональное разделение государственной власти, которое и является основой ее самоограничения. 
Понятие «конституционализм» указывает на общие правовые рамки действий государственной власти, стремящейся воплотить в жизнь идею правового государства государства, действующего в рамках права, ограниченного ими. А поскольку правотворчество и правоприменение входят в число функций государства, то можно говорить о самоограничении государства правом. Конституция, выступающая высшей формой официального закрепления права, также оформляет те базовые процедуры и «правила игры», неукоснительное соблюдение которых делает государство демократическим.

Однако для того, чтобы в современном мире страна заслужила авторитет и подлинное уважение - не за высокие экономические показатели, которых может достичь и диктатура, а именно как демократическое правовое государство, - эта страна должна достичь определенного уровня политико-правового развития, который характеризуется понятием «современная демократия».

Яркое подтверждение данного тезиса дает Ги Каркассонн в эпиграфе к своему знаменитому комментарию к Конституции Французской Республики 1958 года, или Конституции V Республики: «V Республика сделала из Франции современную демократию, но онаможет достичь еще большего ив демократии, ив современности» ${ }^{l}$.

Что же, по мнению Ги Каркассонна, превратило Францию в современную демократию именно в период V Республики? К соблюдению каких условий следует стремиться России, заимствующей, как будет показано далее, многие черты конституционного устройства современной Франции? Ответу на данный вопрос и посвящена данная статья, показывающая, какие уроки мы можем извлечь из Конституции Французской Республики 1958 года.

1. «Заслужить определение «демократия», - полагает Ги Каркассонн, - могли лишь те страны, в которых было необходимо и в то же время было достаточно наличия гарантий свободы и прав человека в общей структуре политической системы, власть которой периодически зависит от свободно и состязательно проводимых выборов. Заслужить определение «современная» может только демократия при ее соответствии одновременно трем условиям:

А) управляемые действительно выбирают управляющих;

Б) управляющие действительно имеют средства для управления;

\footnotetext{
${ }^{1}$ Конституция Франции в комментариях Ги Каркассонна / Пер. с франц. под общ. ред. В.Г.Марача и А.А.Матюхина. Алматы: АЮ-ВШП «Адилет», 2005. с. 24
}

В) управляющие действительно несут ответственность перед управляемыми» ${ }^{2}$.

Для тех, кто знаком с особенностями российской политической жизни, безусловно, особенно актуальным является указание на третье условие. Как замечает по этому поводу сам Ги Каркассонн, «согласно Порталису, «правосудие - это первейший долг суверенитета». Так и ответственность - это первейший долг власти в демократической системе ${ }^{3}$.

За время, прошедшее с момента распада СССР, значительная доля граждан постсоветских государств разуверилась в идеалах демократии. Однако проводимое Ги Каркассонном сквозь всю свою книгу понимание современной демократии, в основе которой лежит принции ответственности управляющих перед управляемыми, вполне способно поколебать этот скептицизм и восстановить в глазах граждан подлинное значение выборов как механизма политической ответственности управляющих: «Эта ответственность должна быть взята в интервале между выборами, но именно во время выборов она и должна получить возможность своего подтверждения, - настаивает автор, предлагая нам для размышления еще ряд весьма актуальных суждений: «Для того, чтобы ответственность осуществлялась в интервале между выборами, необходимо осуществление юридического, политического и общественного контроля за действиями Правительства. Прозрачность власти и свобода прессы являются главными условиями осуществления контроля. Но необходимо также, чтобы Парламент, и в особенности его меньшинство, имели возможность проводить расследование, задавать вопросы и критиковать» ${ }^{4}$.

Как нам хорошо известно, в России, как и в ряде других стран СНГ, вопрос о статусе оппозиции («меньшинства») является весьма болезненным. Не менее актуальное значение имеют и вопросы о свободе прессы и прозрачности власти, которые применительно к деятельности политических партий затрагивают проблемы их финансирования, а также принципы «честных выборов».

И, по нашему мнению, многим законодателям из стран Содружества стоит поучиться у Ги Каркассонна, демонстрирующего в обсуждении этого круга проблем поразительный пример политического реализма: «Конституционный Совет не наделил их (партии)

\footnotetext{
2 Конституция Франции в комментариях Ги Каркассонна / Пер. с франц. под общ. ред. В.Г.Марача и А.А.Матюхина. Алматы: АЮ-ВШП «Адилет», 2005. с. 27

${ }^{3}$ Там же. с. 30

${ }^{4}$ Там же. с. 30
} 
DOI: $10.7256 / 1811-9018.2013 .13 .10520$

При цитировании этой статьи сноска на dоі обязательна

\section{Право и политика $13(168) \cdot 2013$}

правами, но он проследил, чтобы не оказались непризнанными права, вытекающие из текста Конституции... Законодатель... наделил их ресурсами, в обмен на их прозрачность. Таким образом, был положен конец, этому недостойному и губительному притворству, в котором каждый соглашался с тем, что демократия является дорогим удовольствием, но делал вид, что верит тому, что членских взносов достаточно для финансирования расходов партий. Представлены они в Парламенте или нет, в настоящее время партии располагают государственными средствами, они могут получать пожертвования, используя налоговые привилегии, с обязательством ежегодной публикации своих счетов. Демократия выигрывает там, где теряют непрозрачные посредники или некоторые нечестные избранники» ${ }^{5}$.

2. Для конкретного государства важнейшим документом, выражающим принципы демократического правового государства и конституционализма, является его конституция. Конституция Российской Федерации 1993 года закрепляет основные институциональные принцииь правового государства ${ }^{6}$ :

Первым, с точки зрения выражения идеи институционального самоограничения власти, является принцип “подзаконности власти”, подразумевающий, что закон, принимаемый властью, является обязательным и для нее самой, а не только для подвластных, как в полицейском государстве. Важным частным случаем реализации принципа подзаконности власти является связанность действий любой власти (не только исполнительной и судебной, но и законодательной) нормами Конституции.

Признавая себя подзаконной, власть подвергается институционально-правовому самоограничению. Специально подчеркнем, что так было не везде и не всегда. Ср.: “(Ульпиан) Принцепс свободен от (соблюдения) законов”7. Принцип подзаконности власти есть результат длительного генезиса европейской правовой культуры, в ходе которого сформировались Идея Права и культурно-исторические предпосылки верховенства права. Реализуемое абсолютистской властью чистое отношение господства не может быть подзаконно, и только

\footnotetext{
${ }^{5}$ Конституция Франции в комментариях Ги Каркассонна / Пер. с франц. под общ. ред. В.Г.Марача и А.А.Матюхина. Алматы: АЮ-ВШП «Адилет», 2005. с. 46

${ }^{6}$ Марача В.Г., Матюхин А.А. Конституционная власть в странах СНГ: институциональное разделение властей и социальный идеал устойчивого развития. Часть 1 // Вопросы методологии. 1997. №1-2.; Матюхин A.А. Государство в сфере права: институциональный подход. Алматы: ВШП «Адилет», 2000. с. 197-198.

${ }^{7}$ Дигесты Юстиниана. М.: Наука, 1996. D.1.3.31. с. 33
}

институционально ограниченное властное отношение может регулироваться через определенные в законе институциональные процедуры и статус субъекта власти.

Современные особенности применения данного принципа удачно раскрываются рассмотренными выше условиями функционирования «современной демократии» по Каркассонну. «Подзаконная» власть должна иметь возможность исполнить закон, для чего ей необходимы средства управления (второе условие). С другой стороны, в современном демократическом правовом государстве управляющие отвечают перед управляемыми (третье условие) именно и в первую очередь за неисполнение закона - и уж потом за неисполнение предвыборных обещаний и т.п. Выборность же (первое условие) образует механизм политической ответственности перед управляемыми лишь тогда, когда принцип подзаконности соблюден. В противном случае вступают в действие другие механизмы - например, отстранения от должности.

Более того, учредительная власть заботится о том, чтобы выборные лица между выборами лично отвечали толькоза нарушениеуголовного закона. Так, согласно статье 68 Конституции Французской Республики 1958 года «Президент Республики несет ответственность за действия, совершенные в период выполнения своих функций, только в случае государственной измены». А вот как поучительно для российских парламентариев истолковывает Ги Каркассонн логику применения депутатского иммунитета: «Отсутствие ответственности (депутатов) является абсолютным, поскольку оно является абсолютным условием полной свободы слова и убеждения. Таким образом, ни один парламентарий ни на каком основании не может быть обвинен за свое мнение и голосование. Но этот иммунитет, как $и$ другой, предназначен для защиты мандата, а не того, кто им обладает. Вот почему он применяется лишь для актов, прямо связанных с мандатом, - свободы мнения и голосования при его исполнении, - и не затрагивает всех действий депутата. Суждения, высказываемые им во время предвыборной кампании, например, не подпадают под этот иммунитет» ${ }^{8}$

Второй принциип - гарантированность прав личности (человека и гражданина): “Основу прочного правопорядка составляет свобода личности и ее неприкосновенность". В целях противостояния произволу

\footnotetext{
${ }^{8}$ Конституция Франции в комментариях Ги Каркассонна / Пер. с франц. под общ. ред. В.Г.Марача и А.А.Матюхина. Алматы: АЮ-ВШП «Адилет», 2005. с. 118

${ }^{9}$ Кистяковский Б.А. В защиту права (Интеллигенция и правосознание) // Вехи. Из глубины. М.: Правда, 1991. с. 128
} 
власти должны быть созданы реальные возможности защчиты прав и свобод человека - и, прежде всего, через суд. При этом суд из способа преследования или неравноправной тяжбы (инквизиционный суд) становится средством защиты права, местом, где на основе состязательного процесса вершится правосудие, восстанавливается справедливость. Без данного принципа невозможно существование ни гражданского общества, ни общественно-политических институтов (которые, вместе с правовым государством и дополняя его, образуют базис современной государственности).

Отметим, что в русской философии начала века материальной основой свободы личности считалось не право собственности и неприкосновенность последней, как в либерализме XIX века, оставлявшем государству роль «ночного сторожа», а более широкое понятие «права на достойное человеческое существование», предполагавшее более активную и социально-ориентированную позицию государства.

Третий принции - верховенство права через верховенство Конституции, что означает конституционную закрепленность и гарантированность прав личности, человека и гражданина, а также подзаконности власти. Необходимо установление конституциионного порядка, подразумевающего разделение власти и регламентирование законодательной (и вообще нормотворческой) и правоприменительной деятельности. «Общество, в котором не обеспечены гарантии прав и не проведено разделение властей, не имеет Конституции» (статья XVI Декларации прав Человека и Гражданина). Указанный принцип, придающий конституционную значимость и условиям функционирования «современной демократии» по Каркассонну, имеет прямое действие на все ветви власти.

3. Собственно говоря, принцип верховенства права через верховенство Конституции задает важнейшие функции конституции в правовом государстве:

- $\quad$ закрепление в правовом акте высшей юридической силы и гарантирование прав личности, человека и гражданина;

- $\quad$ закрепление конституционного порядка как подзаконности власти конституции.

Подчеркнем, что последняя функция означает не только задание правовых рамок деятельности институтов власти, но также определение самих этих институтов, их отношений между собой и с народом. Но установление разделения властей является важной, но не единственной задачей такого определения.

В условиях, когда усиливаются попытки реструктуризации постсоветского пространства по сценариям внешних сил, действующих хотя и под лозунгами демократии и прав человека, но в собственных интересах, наиболее актуальной задачей закрепления конституционного порядка в государстве является сохранения за ним суверенитета права ${ }^{10}$.

Без суверенитета права, то есть исключительного права народа и уполномоченных им институтов государственной власти самостоятельно определять, что есть демократия, права человека, легитимность власти, справедливость и т.д., невозможен и государственньй суверенитет, невозможно в конечном счете сохранение России как геополитического субъекта и ичивилизационной общуности.

Суверенитет права связан также с государственной идеей, выступающей в качестве основания для самостоятельных суждений и оценок по перечисленным выше важнейшим вопросам. Если такого основания нет, то суждения и оценки по поводу демократии, прав человека, легитимности и справедливости отношений власти и народа становятся несамостоятельными, заимствованными извне - что, в конечном счете, приводит к переносу центра принятия важнейших для государства решений за его пределы ${ }^{11}$. Ярким примером того, как институт государственной власти действует по заимствованным (или навязанным) извне основаниям, является действие Верховного Суда Украины, назначившего в 2004 году не предусмотренный Конституцией страны «третий тур» президентских выборов.

4. Важнейшим условием реализации институтами государственной власти суверенитета права является конституционное определение основных институтов власти, то есть закрепление в конституции их статусов и важнейших полномочий, по возможности исключающее двусмысленную трактовку их действий. Институты власти, получившие такое определение и закрепление, назовем конституичионнылми.

Полномочия конституционных институтов должны быть распределены так, чтобы даже в «чрезвычайных» (по К. Шмиту: «Сувереном является тот, кто принимает решение о чрезвычайном положении» $\left.{ }^{12}\right)$ и

\footnotetext{
${ }^{10}$ Генисаретский О.И. Российская государственность в гражданскоправовой и корпоративной перспективе / Государство. Разграничение полномочий. Доклад Центра стратегических исследований Приволжского федерального округа. Под ред. О.Б. Алексеева, О.И. Генисаретского, П.Г. Щедровицкого. Нижний Новгород Москва: ООО «Издательский дом «Третий Рим», ЦСИ ПФО, 2002.

${ }^{11}$ Шайхутдинов Р.Г. Охота на власть. М., 2005.

${ }^{12}$ Шмит К. Политическая теология. Четыре главы к учению о суверенитете // Антология мировой правовой мысли: В 5 т. / Нац. обществ.науч. фонд; Рук. проекта Г.Ю. Семигин. М.: Мысль, 1999. с. 644
} 
DOI: $10.7256 / 1811-9018.2013 .13 .10520$

При цитировании этой статьи сноска на dоі обязательна

\section{Право и политика 13 (168) 2013}

«революционных» $»^{13}$ ситуациях позволить государству сохранить за собой суверенитет права. В этом смысле чрезвычайно поучительна франиузская модель построения конституционных институтов власти, многие элементы которой заимствованы в Конституции РФ 1993 года. Книга Ги Каркассонна дает нам уникальную возможность глубже познакомиться с этой моделью, глядя на нее не с позиции постороннего человека, и даже не юриста, для которого текст Конституции это свершившийся факт, а глазами одного из авторов самой модели.

Так, например, и во Франции, и в России конституционность решения о проведении «третьего тура» президентских выборов, аналогичного вышеупомянутому решению Верховного Суда Украины, была бы обязательно рассмотрена в Конституционном Совете (Франция) или Конституционном Суде (Россия), который, скорее всего, отменил бы его как противоречащее Конституции. Это действие могли бы осудить как «недемократическое», но никто не смог бы оспорить его как «неправовое».

Вообще, сохранение суверенитета права за государством позволяет ради обеспечения стабильности власти проявлять политическую гибкость. Конституция Франции дает еще один пример подобной политической гибкости, не освоенный пока теми странами СНГ, где в последнее время стали актуальны идеи о переходе к парламентским республикам. В этом смысле французская практика сочетания лидирующей роли Президента с ответственностью Правительства перед Парламентом - гораздо более интересный вариант, допускающий режим «политического сосуществования» Президента, представляющего одну из ведущих политических сил, победившую на президентских выборах, с Национальным Собранием и Правительством, представляющими другую политическую силу, победившую на выборах парламентских.

«Именно здесь, - подчеркивает Ги Каркассонн, - и раскрывается истинная природа режима $\mathrm{V}$ Республики. $\mathrm{Hu}$ президентской, ни полу-президентской, она является просто-напросто парламентской. Юридически она таковой и является, так как ее режим определен как парламентский с момента, когда исполнительная власть становится подотчетной законодательной власти. Она является таковой, в особенности, с политической точки зрения, поскольку, если победа на президентских выборах предоставляет возможности, то лишь законодательные выборы реально приносят власть... Нужно еще раз повторить это, и никогда

${ }^{13}$ Шайхутдинов Р.Г. Охота на власть. М., 2005. не забывать об этом: если центральной является роль, которую играют президентские выборы, но они предоставляют победившему лишь возможности, и только победа на законодательных дает реальную власть» ${ }^{14}$.

5. Одновременно Ги Каркассонн разочаровывает тех, кто возлагает слишком большие надежды на перераспределение полномочий между Президентом, Парламентом и Правительством. Как показывает французский опыт, данная мера имеет свои институциональный смысл, однако не является панацеей. Во всяком случае, сама по себе она еще не гарантирует реальной ответственности Правительства перед Парламентом, хотя на это прямо указывает третий абзац статьи 20 Конституции Французской Республики 1958 года:

«Правительство определяет и проводит политику Нации.

В его распоряжении находятся администрация и вооруженные силы.

Оно ответственно перед Парламентом, согласно условиям и в соответствии с проиедурами, предусмотренными статьями 49 и 50».

Статьи 49 и 50, о которых говорится в последнем абзаце, посвящены вотуму недоверия, который Парламент может вынести Правительству. Как поясняет автор, это «оружие было изобретено для хрупких правительств, а было использовано сильными правительствами с парламентским большинством, которое, однако, они не в состоянии были убедить. Оно было изобретено для того, чтобы заканчивать дебаты, которые не могли завершиться иначе, и было использовано для того, чтобы покончить с ними. Оно было изобретено для того, чтобы депутаты взяли на себя ответственность, а было использовано, чтобы отдалить Правительство от своих» ${ }^{15}$.

Не правда ли, знакомая картина? Достаточно представить себе голосование по любому непопулярному законопроекту, который российское Правительство вносит в Государственную Думу, вынуждая пропрезидентскую фракцию «Единая Россия» разделить политическую ответственность за эти меры. Ведь, в самом деле, не будет же пропрезидентское большинство отправлять в отставку Правительство, проводящее политику Президента...

Для чего же тогда ставится на голосование вопрос о вотуме недоверия? «Чаще всего чтобы начать дебаты,

14 Конституция Франции в комментариях Ги Каркассонна / Пер. с франц. под общ. ред. В.Г.Марача и А.А.Матюхина. Алматы: АЮ-ВШП «Адилет», 2005. с. 51-52

${ }^{15}$ Конституция Франции в комментариях Ги Каркассонна / Пер. с франц. под общ. ред. В.Г.Марача и А.А.Матюхина. Алматы: АЮ-ВШП «Адилет», 2005. с. 180 
- полагает автор. - Это одно из наиболее значимых изменений, внесенных современным парламентаризмом: сомнение в отношении ответственности нигде не является нормальным способом конца правительств. Они поддерживаются политическим большинством, которое остается им верным, более или менее по доброй воле, до следующих выборов. И только исключительные ситуации придают вотуму недоверия его изначальную цель, провоцируя низложение Правительства (один раз в период V Республики, в 1962 г., один раз в Германии в 1982 г., остановив свой выбор на этих двух странах). Из чего следует, что авторы резолюции не строят иллюзий на счет шансов на удачу их вотума, иелью которого является не низложение Правительства, а проведение торжественных дебатов по просьбе меньшинства. Таким образом, вотум недоверия является отныне уже не полномочием Национального Собрания, а одним из элементов статуса оппозиции...

Таким образом, вотум недоверия ставит под сомнение ответственность потенциальную, нежели доказанную, фиктивную, нежели реальную. Но это остается фикиией, необходимой для институциональной игры. Именно она все объясняет, все позволяет, все оправдывает. Что означает: для ее правдоподобности необходимо и достаточно, чтобы существовала сама возможность (принятия вотума недоверия). Оспаривают ли депутаты политику Правительства? Они могут поставить ее под сомнение. Изобличают ли они поведение Правительства, повышенный надзор, который им навязывается? Они могут его низвергнуть. Считают ли они, что Правительство отвечает мало или плохо на их вопросы, что оно с недовольным видом принимает дела к расследованию, что оно злоупотребляет своими прерогативами? Они могут его низложить. Если они не делают этого, то данный факт указывает на то, что они находят у него больше положительных качеств, нежели недостатков. И идет по волнам правительственный корабль, и не в Национальном Собрании он рискует утонуть» ${ }^{16}$.

6. Впрочем, французская модель - в отличие от российской - располагает и другой возможностью: когда парламентское большинство не является пропрезидентским, и, соответственно, политика Правительства в значительной мере самостоятельна по отношению к Президенту. «Когда в действительности оно (Правительство), - поясняет Ги Каркассонн, - имеет полномочия, о которых говорится в первом абзаце ста-

${ }^{16}$ Конституция Франции в комментариях Ги Каркассонна / Пер. с франц. под общ. ред. В.Г.Марача и А.А.Матюхина. Алматы: АЮ-ВШП «Адилет», 2005. с. 176-178 тьи 20, то есть в период сосуществования, противоречия последнего абзаца исчезают, поскольку ситуация ему гарантирует, почти при любом состоянии дел, парламентскую поддержку перед лицом Главы государства. Парадокс заключается в том, что когда Правительство определяет политику Нации, оно, по настоящему, не несет ответственность перед Парламентом, а, в случае, когда оно, в реальности, не определяет политику Нации, оно становится подотчетным Парламенту» ${ }^{17}$.

И еще один интересный фрагмент, характеризующий распределение полномочий между Президентом, Правительством и Премьер-министром: «Обычно, в Совете министров голосование не предусмотрено: с одной стороны, у страны есть Президент, а у Правительства есть его Глава, которые, и один, и другой, имеют полномочия для принятия решений, которые ни одно голосование министров не смогло бы отменить; с другой стороны, Совет министров - это место принятия решений, но не властный орган принятия решений, автором которых он не является» ${ }^{18}$.

Основное же преимущество французской модели заключается не в политической ответственности Правительства, а в том, что наделение Премьерминистра значительными политическими полномочиями позволяет Президенту разрешать возникающие политические противоречия в непосредственном взаимодействии не с Парламентом (как это было в 1993 году в России), не с Верховным Судом и, тем более, не с Майданом (как это было в 2004 году и повторяется в 2013 году в Киеве), а с Премьер-министром. Применение подобных согласительных процедур иногда заставляет Президента отступить, но обладает гораздо меньшим конфликтным потенциалом и никогда не приводит к кризису власти.

7. Попробуем определить то общее, что присуще системе конституционных институтов власти и Франции, и России.

Если выстраивать иерархию статусов институтов власти исходя из их формального определения в Конституции, то наивысшим статусом обладают те институты, которые соответствуют традиционному для политико-правовой мысли понятию «ветвей власти»: Парламент, Правительство, судебная власть. Однако сходным статусом обладают также Президент (институт президентской власти), Конституционный Совет (во Франции) и Конституичионыый Суд (в России), а также органы местного самоуправления.

\footnotetext{
${ }^{17}$ Там же. с. $100-101$

${ }^{18}$ Там же. с. 72
} 
DOI: $10.7256 / 1811-9018.2013 .13 .10520$

При цитировании этой статьи сноска на dоі обязательна

\section{Право и политика $13(168) \cdot 2013$}

Формальным признаком сходства конституционных статусов перечисленных институтов является то, что каждому из этих институтов власти или институц̧иональных комплексов (каковыми следует признать судебную власть и местные органы, поскольку здесь мы имеем не один институт власти, а несколько взаимосвязанных) посвящен самостоятельный раздел Конституции.

Кроме этих специальных разделов Конституции их компетенция, порядок организации и деятельности определяется конституционными законами (для Парламента, Правительства, судебной системы и Конституционного Совета во Франции или Конституционного Суда в России) или обычнылми законами (органы местного самоуправления). Структура органов местного самоуправления устанавливается самими гражданами (часть 2 статьи 131 Конституции РФ) - но полномочия органов местного самоуправления определяются законом на основе части 1 статьи 130, а также статьи 132, которая устанавливает полномочия органов местного самоуправления, в исполнении которых они самостоятельны (часть 1) или подконтрольны государству (часть 2). Институт президентской власти определен непосредственно Конституичией (прямых отсылок к нормативным актам, которые должны конкретизировать нормы Конституции, последняя не содержит), однако часть 3 статьи 81 говорит о том, что Президент Российской Федерации в соответствии с Конституцией Российской Федерации и федеральными законами определяет основные направления внутренней и внешней политики государства, а часть 4 статьи 81 - что порядок выборов Президента Российской Федерации определяется федеральным законом.

Сходство конституционных статусов этих институтов и институциональных комплексов отражается понятием «институциональный компонент власти», которое является расширением традиционного понятия «ветви власти» в рамках современных представлений о разделении властей ${ }^{19}$.

Представление об институциональных компонентах государственной власти, отличных от ее ветвей, возникает

\footnotetext{
${ }^{19}$ Марача В.Г., Матюхин А.А. Правовые институты, сфера права, правовая культура // Научные труды “Адилет” (г. Алматы). 1998. №1(3); Марача В.Г., Матюхин А.А. Президентская власть в политико-правовом пространстве Российской государственности / Политика и политология: актуальный ракурс. Под общ. ред. И.А. Батаниной, М.Ю. Мизулина. Москва-Тула: Изд-во ТулГУ, 2005; Марача В.Г., Матюхин А.А. Социокультурный анализ политико-правового пространства // Научные труды “Адилет” (г. Алматы). 1999. №1(5); Матюхин А.А. Государство в сфере права: институциональный подход. Алматы: ВШП «Адилет», 2000.
}

в рамках институцฺионально-функцииональной теории государственной власти, связывающей последнюю с определенными функииями государственного управления, получающими свое правовое оформление в виде структурного деления власти на ряд компонентов с конституционно закрепленной компетенцией. Идеальный образец такого структурного деления, признанный конституционной нормой во многих странах, в том числе и в России, задает классическая теория разделения властей, подразумевающая три ветви власти: законодательную, исполнительную и судебную (статья 10 Конституции РФ).

Однако, в противовес данной классической теории, анализ разделов Конституции Российской Федерации 1993 года, посвященных государственному управлению, и сопоставление конституционных норм с описанием реальных институтов государственной власти, действующих в РФ, позволяет выделить большее число структурных институциональных компонентов государственной власти.

8. В частности, особая группа конституционных норм, задающих обособленные институты власти, посвящена не только трем «классическим» ветвям власти, но также Президенту Российской Федеращии (как институту - «Президентской власти», или президентуре).

О том, правомерно ли в рамках российской модели разделения властей обособление Президентской власти в качестве «ветви» (т.е. «на равных» с тремя ветвями власти классической теории), в литературе ведется многолетняя дискуссия. Во французской модели президентуры данный вопрос решается путем закрепления за Президентом функции верховного арбитра по отношению к другим институтам власти: «Президент Республики следит за соблюдением Конституции. Он обеспечивает своим арбитражем законное функционирование публичных властей, а также преемственность государства» (статья 5 Конституции Французской Республики 1958 года). Думается, что более близкое знакомство с особенностями функционирования этой модели позволит и российским юристам и политикам определить свои позиции по данному вопросу более разумно и взвешенно.

«В конечном итоге, - полагает Ги Каркассонн, президентские выборы при всеобщем, прямом голосовании упрочили сверхмогущество, часто определяемое как республиканская монархия. Фактически, можно было бы обойтись и без этого, но было бы ложным полагать, что глава исполнительной власти обладает своим первенством только благодаря этому. Достаточно одного взгляда на то, что происходит во всех современных 
DOI: $10.7256 / 1811-9018.2013 .13 .10520$

При цитировании этой статьи сноска на dоі обязательна

Правоведение

демократиях, чтобы констатировать, что британский Премьер-Министр, канцлер Германии, Председатель Правительства Испании, каждый в своей стране, так же могущественны, как и Президент Франции, но, в отличие от него, даже не терпят присутствия второго лица, обременяющего их. Все они, несмотря на второстепенные различия, были избраны посредством все того же всеобщего голосования. Все они, по настоящему, ответственны только перед ним. И, - возражает автор всем критикам данной модели президентуры, - видение в нашей практике французской специфики является достаточно поверхностным подходом» ${ }^{20}$.

Следующий за этим абзацем тезис Каркассонна будет, несомненно, интересен всем тем, кто критикует «республиканскую монархию» за гипертрофирование роли Президента: «И если он грешит, - полагает Каркассонн, - то это не из-за концентрации полномочий в руках главы исполнительной власти, и это присуще не только нашей стране, и, более того, является, при условии определенных мер предосторожности, состоянием современной демократии, а скорее из-за отрицательных последствий, которые могут возникнуть во Франции, пропитанной духом истории, когда один человек совмещуает в себе символ и силу, вечное воплощение Нации и временную власть, трогательную приверженность к образу единства и политическую приверженность к существующим образованиям. Другие режимы разделили эти двойные роли, а у нас они объединены. Там они уже избегают отклонений от нормы, которые нам все еще угрожают» $\rangle^{21}$.

Несмотря на всю разницу точек зрения, совершенно бесспорно то, что закрепленные в конституциях Франции и России (а также ряда других государств СНГ) модели президентуры подразумевают особое положение Президента в системе разделения властей и механизме сдержек и противовесов.

Данная модель всенародно избранного Президента - выразителя общенационального интереса ${ }^{22}$ находит подтверждение в его конституционном статусе главы государства (часть 1 статьи 80 Конституции РФ), а так-

\footnotetext{
${ }^{20}$ Конституция Франции в комментариях Ги Каркассонна / Пер. с франц. под общ. ред. В.Г.Марача и А.А.Матюхина. Алматы: АЮ-ВШП «Адилет», 2005. с. 57

${ }^{21}$ Там же. с. 57

${ }^{22}$ Малиновский В.А. Глава государства суверенного Казахстана. Алматы: ВШП «Адилет», 1998; Марача В.Г., Матюхин А.А. Президентская власть в политико-правовом пространстве Российской государственности / Политика и политология: актуальный ракурс. Под общ. ред. И.А. Батаниной, М.Ю. Мизулина. Москва-Тула: Издво ТулГУ, 2005; Матюхин А.А. Государство в сфере права: институциональный подход. Алматы: ВШП «Адилет», 2000, с. 407-410
}

же «гаранта Конституции Российской Федерации, прав и свобод человека и гражданина» (часть 2 статьи 80).

Как французская, так и российская конституции закрепляют особое положение Президента как бь «над» тремя «классическими» ветвями государственной власти: «В установленном Конституцией Российской Федерации порядке он... обеспечивает согласованное функционирование и взаимодействие органов государственной власти» (часть 2 статьи 80 Конституции РФ). Кроме того, Президент РФ «может использовать согласительные процедуры для разрешения разногласий между органами государственной власти Российской Федерации и органами государственной власти субъектов Российской Федерации, а также между органами государственной власти субъектов Российской Федерации» (часть 1 статьи 85). Эти конституционные положения определяют функции Президента, аналогичные тем, которые в статье 5 Конституции Французской Республики 1958 года названы арбитражныли.

9. Институционально-функциональная теория объясняет появление новых институциональных компонентов власти возникновением новых функций государства. И если три «классические» ветви власти институционализировали выполнение трех «базовых» групп функций государства - законодательной, исполнительной и судебной, то, как показывает пример с арбитражной функцией Президента, взаимодействие ветвей власти порождает новые функиии. В этом смысле государственная власть являет собой развивающийся организм. И там, где органы этого организма взаимодействуют без противоречий, новые функции, возникающие из взаимодействия, могут быть перераспределены между уже имеющимися органами. В случаях же, когда противоречия предопределены самой конституцией организма (в которую, в частности, заложен принцип разделения властей), для выполнения новых функций организм должен «отращивать» новые органы. Именно в этом состоит механизм появления новых институцииональных компонентов власти.

Интересно, что в некоторых случаях для появления нового института власти не требуется даже новых материальных элементов - достаточно возникновения новой функиии. Именно таков генезис Высокой Палаты Правосудия, которая, в соответствии со статьей 68 Конституции Французской Республики 1958 года, судит Президента Республики в случае выдвижения ему обвинения в совершении государственной измены. При этом, в соответствии со статьей 67 , Высокая Палата Правосудия «состоит из членов, избираемых в равном количестве Национальным Собранием и Сенатом из их 
DOI: $10.7256 / 1811-9018.2013 .13 .10520$

При цитировании этой статьи сноска на dоі обязательна

\section{Право и политика $13(168) \cdot 2013$}

состава после каждого полного или частичного обновления палат». Таким образом, новый институт образуется полностью на основе уже имеющегося - Парламента для выполнения несвойственной ему функиии: судебной.

Подчеркнем, что это далеко не очевидное решение. Во всяком случае, Конституция РФ 1993 года, описывая процедуру импичмента Президента, не предусматривает создания для этого особого института власти. Вот как поясняет логику поиска решения данного вопроса во Франции Ги Каркассонн: «Во имя разделения властей, владеюшие властью исполнительной и законодательной не могли быть подчинены судебной власти в условиях общего права, за исключением случаев, когда суды должны были иметь средства оказания давления на руководящих лиц Нации. Именно по этой причине Великобритания изобрела систему, воспроизведенную позднее в других странах: в случае уголовного нарушения членом исполнительной власти нижняя палата выдвигает обвинение, а верхняя палата выносит суждение. Данный выбор был сделан сначала Реставрацией, затем Июльской монархией, и, наконец, III Республикой. Напротив, IV Республика, учредила Высокую Палату, состоящую из тридцати членов, всех избранных Национальным Собранием, на 2/3 из числа парламентариев и на $1 / 3$ вне него. V Республика, не возвращаясь к предшествующей системе, восстановила принцип двухпалатного равновесия одновременно с исключительно парламентским составом $\rangle^{23}$.

Данный пример наглядно показывает, что в вопросах «изобретения» новых институциональных компонентов власти не вреден здоровый консерватизм, и зачастую новое - это хорошо забытое старое. Мировая практика изобрела не так уж много механизмов, обеспечивающих институциональные гарантии соблюдения принципа «подзаконности власти» Главойгосударства. Юристам и политикам изстран СНГ осталось лишь определиться с тем, нужна ли вообще такая ответственность Главы государства в условиях «республиканской монархии». Ги Каркассонн твердо уверен, что нужна - если, конечно, мы стремимся к тому, чтобы стать современной демократией: «Король не может сделать плохо», - гласила монархистская доктрина, перенося таким образом на других любую возможную ответственность. Это несколько меньше того, что говорится о Президенте в республиканской доктрине. Он мог тем не менее сделать плохо, как он не мог сделать что-либо великое $)^{24}$.

\footnotetext{
${ }^{23}$ Конституция Франции в комментариях Ги Каркассонна / Пер. с франц. под общ. ред. В.Г.Марача и А.А.Матюхина. Алматы: АЮ-ВШП «Адилет», 2005. с. 227

${ }^{24}$ Конституция Франции в комментариях Ги Каркассонна / Пер. с франц. под общ. ред. В.Г.Марача и А.А.Матюхина. Алматы: АЮ-ВШП «Адилет», 2005. с. 228
}

Заслуживает упоминания и проблема взаимодействия президентской и судебной властей. Первый абзац статьи 64 Конституции Французской Республики 1958 года гласит: «Президент Республики является гарантом независимости судебной власти». Комментарий Ги Каркассонна весьма едок: «Первый абзац данной статьи является нелепым. Это означало бы, что волк является гарантом безопасности овчарни». И далее: «Любая политическая власть, какой бы она ни была, до недавнего времени изыскивала пути сделать суды такими послушными, о каких она могла только мечтать, а ее мечтания были ненасытными... Но правда и то, что сами судьи в течение долгого времени предоставили Франции лишь редкие доказательства того, за что бы их можно было уважать больше, чем они уважали себя сами. За исключением нескольких заслуживающих случаев в истории судопроизводства, судьи в своей селективной суровости доказали исключительное и чревоугодное усердие, а в своей зависимости - слепую покорность» ${ }^{25}$.

Не правда ли, знакомая картина? К чести Франции нужно отметить, что в период $\mathrm{V}$ Республики эта недопустимая с точки зрения современной демократии ситуация была преодолена. Решение было гениально простым, хотя его реализация потребовала величия личности Шарля да Голля, который «не ошибся в том, что без колебаний поставил судебную сферу на одну планку с военной, гражданской или министерской, с целью показать, что каждая из них имеет власть, доверенную и поддержанную им» ${ }^{26}$. Редкий в истории случай, когда конституционная норма со столь неформальным содержанием была реализована буквально: Президент Республики действительно выступил гарантом независимости судебной власти.

10. Рассмотрение институциональных компонентов власти не может ограничиться анализом конституционных и иных законодательно установленных норм, поскольку институт власти не сводится к «совокупности норм, регулирующих однородные общественные отношения». Если следовать трактовке основателя институционализма выдающегося французского правоведа и социолога М. Ориу, то в последнем случае мы имеем дело с институтом-вещью, тогда как институты власти - это институты-корпорации ${ }^{27}$, представляющие собой не просто совокупности норм, но и реализующие их сочиальные организачии (учреждения), деятель-

\footnotetext{
${ }^{25}$ Там же. с. 218

${ }^{26}$ Там же. с. 219

${ }^{27}$ Ориу M. Основы публичного права. Пер. с франц. под ред. Е. Пашуканиса и Н. Челяпова. М.: Изд-во Ком. акад., 1929. с. 114-116
} 
ность которых подчинена определенным принципам и предназначению, которое М. Ориу называет «направляющей идеей». Если принципы и предназначение института оставляются вне рассмотрения, то мы снова возвращаемся к вещной трактовке институтов - позитивистской редукции, сводящей социальные учреждения к «социальным телам», лишенным «души», то есть осуществляющем деятельность нерефлексивно, безотносительно кее культурному смыслу.

В рамках институционально-функциональной теории государственной власти предназначение как раз и есть идеальныци, культурно-значимый смысл, стоящий за совокупностью функций, приписываемых данному институту. В соответствии со схемой состава института функции процессуально «расписываются» в виде системы формальных мест и процедур «функционирования» института как социального учреждения - а предназначение (как и принципы) выступает содержательным выражением институцчиональной идеи. Разница состоит в том, что принципы выражают идею нормативно (в качестве примера см. принципы осуществления правосудия и устройства судебной системы, зафиксированные в статьях 46-52 и 118-124 Конституции РФ), а предназначение - телеологически (например, предназначение институтов Верховного и Высшего Арбитражного судов Российской Федерации закреплено статьями 126-127 Конституции РФ).

Если функции института могут существовать как относительно независимые «кирпичики», то предназначение в силу данной выше телеологической трактовки подразумевает не только «высшую» цель, но и цеельность. За совокупностью функций института должен рефлексивно восстанавливаться достаточно целостный культурный смысл его функционирования, передаваемый (транслируемый) сменяющим друг друга участникам (и поколениям участников) института, что обеспечивает преемственность и воспроизводство последнего.

11. То, что является общим в предназначении всех конституционных институтов власти и превращает их в слаженно функционирующие звенья разделенного на институциональные компоненты, но в то же время единого механизма государственной власти, и есть государственная идея.

Именно государственная идея является основанием для самостоятельных суждений и оценок, позволяющих сохранять суверенитет права и, в конечном счете, государственный суверенитет (см. п. 3 данной статьи).

Именно государственная идея становится «общим знаменателем» для взаимодействия сторон полити- ческого конфликта при применении согласительных процедур, позволяя им находить общий язык, понимать друг друга и приходить к компромиссному решению.

Именно государственная идея, соответствуя культурным традициям и ментальности народа, соотносясь с духовными опорами конституционных институтов власти и государства в целом, обеспечивает легитимность последнего в восприятии граждан.

12. Каково соотношение государственной идеи и Конституции?

Конституция - это своего рода «институт институтов», поскольку, будучи институтом сама, она создает одно из необходимых условий институционализации власти в правовом государстве и слаженности функционирования всех конституционных институтов власти в правовом поле. И поэтому именно Конституция, определяя статус и предназначение конституциионных институтов власти, является наиболее емким и развернутым выражением государственной идеи в нормативно-правовой форме.

В конечном счете, магистральный путь становления правового государства состоит в укреплении духовных опор его конституционных институтов, в дальнейшем укоренении в сознании и граждан, и представителей власти, включая законодателей, идей и ценностей конституционализма и законности. И по мере продвижения страны по этому цивилизационному пути, несомненно, будет снижаться актуальность восполнения недостатка правовой культуры посредством «силовых» структур. Правовое государство должно быть сильным, но эта сила должна проявляться в рамках ограниченных конституционныл полем состязательных институтов: в залах судов, Парламента, Конституционного Суда, в согласительных процедурах, а не вне их.

13. Конституция - не только правовой институт, но, будучи выражением принципа верховенства права, она является также и авторитетнылм институтом власти 8 правовом государстве $e^{28}$. Как и другие институты государственной власти, Конституция - это не только совокупность норм, но и институт-корпорация.

\footnotetext{
${ }^{28}$ Марача В.Г., Матюхин А.А. Конституционная власть в странах СНГ: институциональное разделение властей и социальный идеал устойчивого развития. Часть $1 / /$ Вопросы методологии. 1997. №1-2; Марача В.Г., Матюхин А.А. Конституционная власть в странах СНГ: институциональное разделение властей и социальный идеал устойчивого развития. Часть 2 // Вопросы методологии. 1997. №3-4; Матюхин А.А. Государство в сфере права: институциональный подход. Алматы: ВШП «Адилет», 2000, С. 417-427.
} 
DOI: $10.7256 / 1811-9018.2013 .13 .10520$

При цитировании этой статьи сноска на dоі обязательна

\section{Право и политика 13 (168) 2013}

Непосредственным организационным механизмом обеспечения действия Конституции РФ 1993 года (который можно назвать «конституционной властью») является орган конституиионного контроля/надзора Конституциионный Суд.

В широком смысле к этому организационному механизму следует добавить деятельность Президента в качестве символа и гаранта Конституции, а также прописанные в конституционном законодательстве права обрамения в Конституционный Суд Парламентом, судамии гражданами с челью получения офичиального толкования и устранения возможных конституционных деликтов.

14. С момента, когда многонациональный российский народ принял Конституцию 1993 года, прошло двадцать лет. За это время Конституция укрепила свой авторитет, и участники законодательного процесса, а также все, кто уполномочен применять действующее право, не раз убеждались в ее мудрости.

Однако жизнь не стоит на месте. Россия изменяется. За двадцать лет появились и новые вызовы времени международный терроризм, а также ставшее реакцией на это возрастающее стремление некоторых государств навязывать миру собственное понимание свободы, демократии и т.д. Отвечает ли этим новым вызовам действующая Конституиия?

В Российской Федерации уже принимались поправки к Конституции, касающиеся изменения наименований субъектов РФ, а также сроков, на которые избираются Президент РФ и Государственная Дума. Готовятся изменения, направленные на объединение Верховного и Высшего Арбитражного судов. Можем ли мы сказать, что пришло время для более серьезных изменений? Думается, такой вывод будет преждевременным.

Однако было бы весьма актуально и полезно для страны, если бы ведущие ученые - правоведы, политологи, специалисты по международным отношениям, экономисты подготовили бы проблемно-исследовательский комментарий к действующей Конституции. Прекрасный образец подобной работы дает нам книга, написанная Ги Каркассонном.

Важнейшей задачей такой работы было бы ответить, насколько содержание норм Конституции отвечает вызовам времени, а также оценить, позволяют ли имеющиеся организачионные механизмы реализации конституциионных норм решать задачи укрепления легитимности институтов государственной власти, сохранения за Россией суверенитета права? Какие здесь могут быть разрывы, сбои взаимодействия институтов государственной власти между собой и с гражданами, или какие могут возникать искажения правопонимания? Что еще нужно сделать для того, чтобы Россия с полным правом могла назвать себя современным демократическим государством - в том смысле понятия «современная демократия», который нам на примере Французской Республики - убедительно показал Ги Каркассонн.

Нет сомнений, что обсуждение достоинств и недостатков действующей Конституции не обойдется без ссылок на зарубежный опыт. И это правильно. Однако совершенно недопустимо, когда такой опыт является исключительным достоянием специалистов. Ведь известно (и здесь Ги Каркассонн преподает нам еще один урок современной демократии), что «специалистами всегда являются те, кто присваивает себе специализированные процедуры. И среди них самыми активными являются самые мотивированные» ${ }^{29}$. И для того, чтобы общественное мнение не стало жертвой политических манипуляций подобных «мотивированных специалистов» (на постсоветском пространстве их называют «политтехнологами»), вышеупомянутый зарубежный опыт должен быть доступен широкой публике.

Только после появления и самого широкого обсуждения такого авторитетного комментария можно будет решать, нужны ли изменения действующей Конституции - правового документа, прослужившего стране десять лет и полностью оправдавшего возлагавшиеся на него надежды. Во второй части эпиграфа к своему комментарию Ги Каркассонн пишет, что Франция «может достичь еще большего и в демократии, и в современности». Хочется верить, что может достичь большего и Россия.

\section{Библиография:}

1. Генисаретский О.И. Российская государственность в гражданско-правовой и корпоративной перспективе / Государство. Разграничение полномочий. Доклад Центра стратегических исследований Приволжского федерального округа. Под ред. О.Б. Алексеева, О.И.Генисаретского, П.Г.Щедровицкого. Нижний Новгород-Москва: ООО «Издательский дом «Третий Рим», ЦСИ ПФО, 2002.

2. Дигесты Юстиниана. М.: Наука, 1996. D.1.3.31.

3. Кистяковский Б.А. В защиту права (Интеллигенция и правосознание) // Вехи. Из глубины. М.: Правда, 1991.

\footnotetext{
${ }^{29}$ Конституция Франции в комментариях Ги Каркассонна / Пер. с франц. под общ. ред. В.Г.Марача и А.А.Матюхина. Алматы: АЮ-ВШП «Адилет», 2005. с. 257
} 
DOI: $10.7256 / 1811-9018.2013 .13 .10520$

При цитировании этой статьи сноска на doi обязательна

Правоведение

4. Конституция Франции в комментариях Ги Каркассонна / Пер. с франц. под общ. ред. В.Г.Марача и А.А.Матюхина. Алматы: АЮ-ВШП «Адилет», 2005.

5. Малиновский В.А. Глава государства суверенного Казахстана. Алматы: ВШП «Адилет», 1998.

6. Марача В.Г., Матюхин А.А. Конституционная власть в странах СНГ: институциональное разделение властей и социальный идеал устойчивого развития. Часть 1 // Вопросы методологии. 1997. №1-2.

7. Марача В.Г., Матюхин А.А. Конституционная власть в странах СНГ: институциональное разделение властей и социальный идеал устойчивого развития. Часть 2 // Вопросы методологии. 1997. №3-4.

8. Марача В.Г., Матюхин А.А. Правовые институты, сфера права, правовая культура // Научные труды “Адилет” (г. Алматы). 1998. №1(3).

9. Марача В.Г., Матюхин А.А. Президентская власть в политико-правовом пространстве Российской государственности / Политика и политология: актуальный ракурс. Под общ. ред. И.А. Батаниной, М.Ю. Мизулина. Москва-Тула: Изд-во ТулГУ, 2005.

10. Марача В.Г., Матюхин А.А. Социокультурный анализ политико-правового пространства // Научные труды “Адилет” (г. Алматы). 1999. №1(5).

11. Матюхин А.А. Государство в сфере права: институциональный подход. Алматы: ВШП «Адилет», 2000.

12. Ориу М. Основы публичного права. Пер. с франц. под ред. Е. Пашуканиса и Н. Челяпова. М.: Изд-во Ком. акад., 1929.

13. Шайхутдинов Р.Г. Охота на власть. М., 2005.

14. Шмит К. Политическая теология. Четыре главы к учению о суверенитете // Антология мировой правовой мысли: В 5 т. / Нац. обществ.-науч. фонд; Рук. проекта Г.Ю. Семигин. М.: Мысль, 1999.

\section{References (transliteration):}

1. Genisaretskii O.I. Rossiiskaya gosudarstvennost' v grazhdansko-pravovoi i korporativnoi perspektive / Gosudarstvo. Razgranichenie polnomochii. Doklad
Tsentra strategicheskikh issledovanii Privolzhskogo federal'nogo okruga. Pod red. O.B. Alekseeva, O.I. Genisaretskogo, P.G. Shchedrovitskogo. Nizhnii Novgorod - Moskva: OOO «Izdatel'skii dom «Tretii Rim», TsSI PFO, 2002.

2. Digesty Yustiniana. M.: Nauka, 1996. D.1.3.31.

3. Kistyakovskii B.A. V zashchitu prava (Intelligentsiya i pravosoznanie) // Vekhi. Iz glubiny. M.: Pravda, 1991.

4. Konstitutsiya Frantsii v kommentariyakh Gi Karkassonna/Per. s frants. pod obshch. red. V.G.Maracha i A.A.Matyukhina. Almaty: AYu-VShP «Adilet», 2005.

5. Malinovskii V.A. Glava gosudarstva suverennogo Kazakhstana. Almaty: VShP «Adilet», 1998.

6. Maracha V.G., Matyukhin A.A. Konstitutsionnaya vlast' v stranakh SNG: institutsional'noe razdelenie vlastei i sotsial'nyi ideal ustoichivogo razvitiya. Chast' $1 / /$ Voprosy metodologii. 1997. №1-2.

7. Maracha V.G., Matyukhin A.A. Konstitutsionnaya vlast' v stranakh SNG: institutsional'noe razdelenie vlastei i sotsial'nyi ideal ustoichivogo razvitiya. Chast' 2 // Voprosy metodologii. 1997. №3-4.

8. Maracha V.G., Matyukhin A.A. Pravovye instituty, sfera prava, pravovaya kul'tura // Nauchnye trudy “Adilet” (g. Almaty). 1998. №1(3).

9. Maracha V.G., Matyukhin A.A. Prezidentskaya vlast' v politiko-pravovom prostranstve Rossiiskoi gosudarstvennosti / Politika i politologiya: aktual'nyi rakurs. Pod obshch. red. I.A. Bataninoi, M.Yu. Mizulina. Moskva-Tula: Izd-vo TulGU, 2005.

10. Maracha V.G., Matyukhin A.A. Sotsiokul'turnyi analiz politiko-pravovogo prostranstva // Nauchnye trudy “Adilet” (g. Almaty). 1999. №1(5).

11. Matyukhin A.A. Gosudarstvo v sfere prava: institutsional'nyi podkhod. Almaty: VShP «Adilet», 2000.

12. Oriu M. Osnovy publichnogo prava. Per. s frants. pod red. E. Pashukanisa i N. Chelyapova. M.: Izd-vo Kom. akad., 1929.

13. Shaikhutdinov R.G. Okhota na vlast'. M., 2005.

14. Shmit K. Politicheskaya teologiya. Chetyre glavy k ucheniyu o suverenitete // Antologiya mirovoi pravovoi mysli: V 5 t. / Nats. obshchestv.-nauch. fond; Ruk. proekta G.Yu. Semigin. M.: Mysl', 1999. 